This item was submitted to Loughborough's Research Repository by the author.

Items in Figshare are protected by copyright, with all rights reserved, unless otherwise indicated.

\title{
The cyclical behaviour of European bank capital buffers
}

PLEASE CITE THE PUBLISHED VERSION

http://dx.doi.org/10.1016/j.jbankfin.2007.12.001

PUBLISHER

(C) Elsevier B.V.

VERSION

SMUR (Submitted Manuscript Under Review)

LICENCE

CC BY-NC-ND 4.0

REPOSITORY RECORD

Jokipii, Terhi, and Alistair Milne. 2019. "The Cyclical Behaviour of European Bank Capital Buffers". figshare. https://hdl.handle.net/2134/15157. 
This item was submitted to Loughborough's Institutional Repository (https://dspace.lboro.ac.uk/) by the author and is made available under the following Creative Commons Licence conditions.

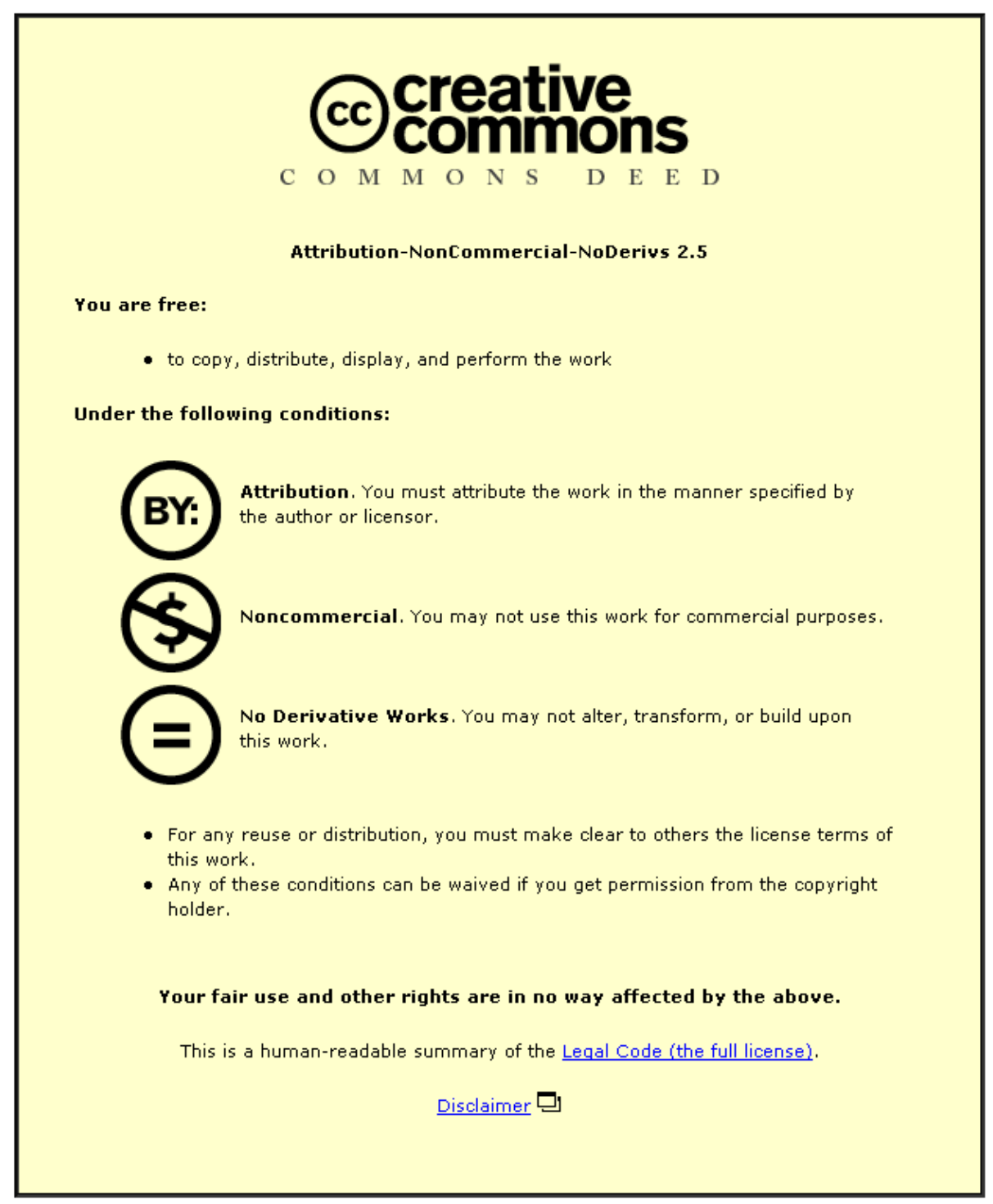

For the full text of this licence, please go to: http://creativecommons.org/licenses/by-nc-nd/2.5/ 


\title{
The Cyclical Behaviour of European Bank Capital Buffers"
}

\author{
by \\ Terhi Jokipii* \\ and \\ Alistair Milne \\ October 2006
}

\begin{abstract}
We examine the cyclical behaviour of European bank capital buffers using an unbalanced panel data set comprising eight years (1997-2004) of bank balance sheet data for commercial, savings and co-operative banks. Controlling for other potential determinants of bank capital, we find that capital buffers of the banks in the accession countries (RAM10) have a significant positive relationship with the cycle, while for banks operative in the EU15 and the EA and the combined EU25 the relationship is significantly negative. We also find fairly slow speeds of adjustment, with around two-thirds of the correction towards desired capital buffers taking place each year. We further distinguish by type and size of bank, finding that capital buffers of commercial and savings banks, and also of a sub-sample of large banks, exhibit negative co-movement. Co-operative banks and smaller banks on the other hand, tend to exhibit positive cyclical co-movement.
\end{abstract}

Key words: Bank Capital, Bank Regulation, Business Cycle Fluctuations

JEL classification numbers: G21, G28

\footnotetext{
^ We would like to thank Antonello D'Agostino, Ari Hyytinen, Giuliano Iannota, Esa Jokivuolle, Juha Kilponen, Jukka Vauhkonen and Matti Virén as well as the audiences of the XXVIII Kansantaloustieteen Päivät 2006, The 2006 European Banking Symposium held at Bocconi University, The Journal of Banking and Finance 30th Anniversary Conference as well as internal Bank of Finland workshops for their very useful comments and suggestions.

- Bank of Finland and Stockholm School of Economics. Terhi.Jokipii@hhs.se; Department of Finance, SE-113 83 Stockholm, Sweden. +46-8-728-5124.

- Bank of Finland and Cass Business School. A.K.L.Milne@city.ac.uk; Cass Business School London, Faculty of Finance, London EC2Y 8HB; +44-(0)20-7477-8738.
} 


\section{Introduction}

Much debate surrounding the new Accord (Basel II) on bank capital requirements, due to come into force in 2007, has centred on its potential 'pro-cyclicality'. One of the primary aims of Basel II is to create a closer link between capital requirements and risks, so it is clear that these requirements will become more dependent on the business cycle. In a cyclical downturn, when counterparties are more likely to be downgraded than upgraded, the resultant effect could be a significant increase in the capital requirements to account for increased counterparty risk. Similarly, during an economic upturn, the amount of capital required would be reduced. Since raising capital is costly, especially during an economic recession when profits are decreasing, banks might be forced to reduce their loan portfolio in a recession, so as to meet rising capital requirements. Thus many have argued that the new Accord will make it much harder for policy makers to maintain macroeconomic stability.

The growing literature on the potential pro-cyclicality of Basel II has largely focussed on quantifying the likely range of variation in 'Pillar 1' capital requirements through the business cycle. ${ }^{1}$ In practice, well-functioning banks hold capital well in excess of the minimum requirements, which will reduce the impact of Pillar 1 regulatory capital requirements on loan portfolios. Moreover, the supervisory review powers granted to regulators under Pillar 2, allowing them to demand a buffer of additional capital during a business cycle expansion, provide policy makers with a tool to counter the potential pro-cyclicality effect of the new accord. Al this implies that the management of bank capital buffers over the course of the business cycle will be as or even more important than the 'Pillar 1' requirements as a determinant of the cyclical impact of the new capital regulations.

With this policy concern in mind, we investigate the behaviour of bank capital buffers of European banks, under the old Basel 1988 accord on capital regulation. By 'capital buffer' we mean the amount of capital banks hold in excess of that required of them by national regulators. The main objective of our paper is to establish the extent of co-movement between this buffer and the cycle, and to determine whether such co-movement is country, bank type or bank size specific. We also analyse the impact of various cost and revenue variables on the behaviour of bank capital buffers.

Our estimation results reveal substantial differences in the cyclical behaviour of capital buffers between the various sub-groups. We find that capital buffers of RAM (10 countries that joined the EU in May 2004) banks appear to move together with

\footnotetext{
${ }^{1}$ Basel II is based on three complementary pillars. Pillar 1 consists of the regulatory calculations of capital requirements for market, credit, and operational risk. Pillar 2 is the supervisory review process, where supervisors assess both the bank's total capital adequacy for the full range of risks including those not covered by Pillar 1 and the bank's management of capital. Pillar 3 is market discipline. In order to improve transparency of banks to counterparties and investors, banks will be required to disclose detailed information on their risk profile and capital adequacy.
} 
the business cycle while the buffers of banks operative in the EU25, EU15, Denmark, Sweden and the United Kingdom (DK,SE,UK) and EA samples rather exhibit negative co-movement. The latter finding is broadly in line with most of the individual country studies that analyse the determinants of excess capital and their relationship to the cycle (see among others Ediz et al., 1998; Rime, 2001; Ayuso et al., 2004; Bikker and Metzemakers, 2004; Lindqvist, 2004; Stoltz and Wedow, 2005).

Breaking the sample down further by size and type of bank, we find additional distinctions. Capital buffers of commercial and savings banks, as well as those of larger banks have a negative relationship with the cycle while those of co-operative banks and of smaller banks move together with the cycle. With regard to the associated costs, in almost all cases we find a fairly slow speed of adjustment towards desired capital buffers. These results provide a benchmark from which inferences relating to the introduction of Basel II and its effect on capital buffer management can be made. In particular, they shed some light on how capital management decisiosn may need to be adjusted through Pillar II and III of Basel II in order to offset the potential cyclical effects of the new accord.

The paper is organized as follows. Section 2 discusses the motivation for holding excess capital, sets out the hypotheses we test, and describes our data including the various controls we introduce for the non-cyclical determinants of bank capital. We can only test hypotheses about the reduced form cyclical behaviour of capital buffers. Section 3 presents our specification and empirical results together with some robustness checks. Finally, section 4 concludes.

\section{Hypotheses and Data Description}

Our data, for the years 1997-2004, reported in Table 1, indicates that banks hold far more prudential capital than that required by the regulators. ${ }^{2}$ Tier 1 capital buffers of banks within the EU15 vary from 1.87 percent of risk-weighted assets in Portugal to 4.79 percent in Finland with an average across the EU15 of 2.93 percent. Buffers are also substantial in the accession countries, ranging between 2.64 percent in Cyprus and 6.99 in Malta. The average buffer for the RAM10 is around 5.14 percent which is considerably larger than in the EU15.

Several reasons have been put forward to explain why banks hold excess capital (see amongst other studies Marcus, 1984; Berger et al., 1995; Jackson et. al., 1999; Milne and Whalley, 2001; Estrella, 2004; Milne, 2004). Banks generally will tend to assess their risks differently than regulators, for instance using their own internal economic capital models. Appropriate bank-specific capital levels will therefore be set according to their own assumptions and risk appetites. Banks may also need to hold excess capital in order to signal soundness to the market and satisfy the expec-

\footnotetext{
${ }^{2}$ Similarly large capital buffers are also held by US and Asian banks. See for example Peura and Jokivuolle (2004) for a tabulation of US capital buffers.
} 
tations of rating agencies (Jackson et. al., 1999). These 'market disciplines' may lead banks to holding more capital required by regulators.

Banks may also hold a buffer of capital as a protection against the violation of the regulatory minimum requirements (Marcus, 1984; Milne and Whalley, 2001; Milne, 2004). By holding capital as a buffer, banks insure themselves against costs arising from a supervisory intervention in response to a violation of the requirements.

A further reason for holding a capital buffer is to take advantage of future 'growth opportunities', putting banks in a position to obtain wholesale funds quickly and at a competitive rate of interest in the event of unexpected profitable investment opportunities. In the event of a substantial increase in loan demand, banks with relatively little capital may lose market share to those that are well capitalised.

It is difficult to empirically distinguish these different underlying determinants of bank capital buffers: for example higher portfolio volatility can be expected to increase capital buffers, whether these are the result of market disciplines or of a desire to avoid supervisory interventions. Our paper has a more limited objective, to investigate how capital buffers of European banks behave over the business cycle, and in particular whether capital buffers are higher in business upturns and lower in business downturns (positive co-movement) or the reverse (negative co-movement), controlling as far as we can for various bank specific determinants of capital buffers..

We thus test the following null hypothesis: $H_{0}$ Under the Basel I Accord, business cycle fluctuations do not have an impact on the capital buffers of European banks; against two alternatives: $H_{1}(a)$ Capital buffers co-move positively with the business cycle i.e. banks tend to increase capital in business cycle expansions and reduce capital in recessions; and $H_{1}(b)$ Capital buffers co-move negatively with the business cycle i.e. banks tend to reduce capital in business cycle expansions and increase capital in recessions.

These descriptive hypotheses are consistent with a number of different underlying structural models of bank capital dynamics. Estrella (2004) examines the relationship between optimal forward looking capital buffers and deterministic cycles of loan losses. He finds that banks, subject to costs of capital adjustment, will build up capital buffers in anticipation of loan losses. Since loan losses themselves tend to lag the business cycle, this suggests that actual capital buffers will rise during cyclical downturns, i.e. negative cyclical co-movement.

It is also argued (see amongst others Rajan, 1994; Borio et al., 2001; Crockett, 2001) that portfolio risks actually increase during an economic upturn. During an economic boom, lenders provide large amounts of credit while imbalances that will become responsible for the following recession continue to build up, increasing the possibility of unusually large losses during a cyclical downturn. Under this interpretation rational forward looking banks may build up capital buffers during cyclical upturns, i.e. positive co-movement. 
Both positive and negative co-movement may also arise as a consequence of myopic bank behaviour. For example during an economic upturn, when risks are less likely to immediately materialise, banks may underestimate risks and as a result expand their loan portfolios and lower their capital ratios (negative co-movement). On the other hand unanticipatedly high levels of loan-loss provisions in an extended cyclical downturn may lead to lower capital ratios in a deep recession (positive comovement)

While we cannot distinguish these different structural models of bank capital buffers, or distinguish myopic from forward looking expectations, we can control for institution specific factors that influence the banks desired level of capital. A large body of literature examines variations in risk profile and portfolio and capital structure decisions between different types of banks (see among others, Saunders et al., 1990; Gorton and Rosen, 1995; Esty, 1997; Salas and Saurina, 2002b). Differences in capital buffers can arise because of variations, in portfolio risks, in ownership structures and in access to the capital market.

The clearest prediction of this literature is that larger banks will hold smaller average capital buffers. Most obviously, large geographically diversified banks will have a much smaller probability of experiencing a large decline in their capital ratios, a diversification effect increasing with size. This effect is reinforced by asymmetric information between lenders and borrowers and by government support for banks that are 'too big to fail'. Banks help overcome information asymmetries by screening and monitoring borrowers, but these are costly activities and banks are likely balance the cost of (and gain from) these activities against the cost of excess capital. In the presence of scale economies in screening and monitoring, one would expect large banks to substitute relatively less of these activities with excess capital. Large banks may expect a greater degree of support than small banks from the government in the event of difficulties, further reducing capital buffers.

\section{Sample selection}

We build an unbalanced panel data set with eight years of annual bank balance sheet data obtained from the Bureau Van Dyck Bankscope database. Our sample includes data for commercial, savings and co-operative banks. In total, 468 banks are included in the sample, made up of 364 EA banks, 427 EU15 banks and 41 banks for the RAM10 (the 10 accession countries that joined the European Union in 2005). All 25 European Union countries are represented in the sample. As is usual in panel studies using accounting data, we remove some extreme outlier observations of changes in capital buffers. ${ }^{3}$

\footnotetext{
${ }^{3}$ Of the total [] observations available to us , we dropped [] in the extreme tails of the cross sectional distribution of capital buffers, at a much larger number of standard deviations from the mean than the bulk of observations. Of these dropped oservations [] were declines in capital buffers below -[] and the remaining [] were increases above [].
} 
The largest bank in the samples is BNP Paribas, with total assets of around EUR 906 bln at the end of 2004. The smallest bank, Budapest Bank in Hungary, has total assets amounting to just around EUR 1.5 million at the end of 2004. The distribution of banks in the sample is presented in Table 3, with the largest number of banks in France (103 banks) and Spain (70 banks) from the EU15 and in Poland (10 banks) for the RAM10.

Our sample is further broken down by bank type distinguishing between commercial, co-operative and savings banks. We additionally differentiate between 'small' and 'large' banks, defining large banks as those with total assets exceeding the 2004 median of EUR 37 billion in 2004. The sample distribution across countries, by type and size of bank, is presented in Table 3. The RAM10 sub-sample is made up of small commercial banks, with the exception of a small Polish savings bank, Powszechna Kasa Oszczednosci Bank. We divide the EU15 into two further subsamles, the Euro area (EA) and Denmark, Sweden, and UK (DKSEUK). The two sub-samples and the total EU15 contain a similar breakdown of banks, with 19 percent of banks large and with 65 percent commercial banks, 15 percent co-operative banks and around 20 percent savings banks. Acrorss the entire data set Sweden has the largest percentage of 'large' banks (around 50 percent), followed by Ireland (around 35 percent).

\section{Dependent and explanatory variables}

Table 1 tabulates average capital buffers in our sample, by time and by country. Here the capital buffer is measured as the institutions' total Tier 1 plust Tier 2 capital Basel 1 risk-weighted capital ratio less its regulatory minimum requirements. These requirements vary slightly from one country to another, as summarised in Table 2, sometimes exceeding the Basel minimum of $8 \%$. The individual country averages are obtained by weighting the buffer by the market share (total assets) of the individual banks. There are several differences in the buffer sizes between countries. Many of the smaller countries such as Finland, Belgium and Ireland have large buffers of around 4 percent when compared to banks in larger countries such as France and Italy and the UK, where the buffers are around two percent above the required minimum.

On average over our sample period RAM10 banks held far more capital than banks in the EU15 countries (see the un-weighted averages of the composite countries at the bottom of Table 1.). However this gap has declined over time. Figure 1 plots the evolution of our individual sub-sample capital buffers. In the EU15 capital buffers rose slightly between 1998 and 1999, but then increased substantially between 2002 and 2003. In the RAM10 countries capital buffers have behaved very differently, rising steadily from 1997 to 1998 before falling sharply between 2000 and 2001. Thereafter, the RAM10 buffer level continues on a slight downward trend and by 2004 is at a similar level to the EU15.

In Figure 2, we plot the evolution of capital buffers over time, distinguish between different bank types and bank sizes, for our four sub-samples, and compares these buffers with our principal explanatory variable, the output gap. The capital 
buffers of co-operative banks behave very differently than those of commercial and savings banks. This is unsurprising considering large differences in ownership structure and objectives of co-operative banks. Moreover, the difficulty that co-operative banks face in increasing their capital base to match growth in business opportunities when compared to commercial and savings banks, can additionally affect the behaviour of their buffers over time. ${ }^{4}$ This figure also confirms that small banks hold much higher average capital buffers than large banks.

Table 4 provides definitions of the remaining variables used in our estimation. Our cyclical indicator is real GDP growth caclauted from Eurostat data for each of the 25 countries and for the different sub-sample country groupings. ${ }^{5} 6$

We have to consider carefully the timing of Since balance sheet data reported in 2004 will most likely reflect economic conditions in 2003, we take the first lag of each cycle variable. By using first lags, rather than the cycle variables in levels, we are able to attain a more accurate picture of the actual relationship that exists between the cycle and the buffer variable. In this paper we present results separately for the broad and the individual country real GDP growth variables only.

Our basic specification (model specification 1) controls for individual bank expected revenues, the cost of failure and the cost of capital adjustment. These cost variables can be interpreted as proxies for the determinants of capital buffers in the theoretical model provided by Estrella (2004). The first of these determinants is the greater cost of equity capital funding, relative to deposits or debt. Theoretical analysis (see Myers and Majluf, 1984; Campbell, 1979) suggests that in the context of information asymmetries, equity is a more costly alternative to other bank liabilities. Equity may also be relatively disadvantaged because interest payments on debt are deducted from earnings before tax.

Direct measurement of this cost is difficult. Previous studies have included the banks return on equity ( $R O E$ ), the ratio of post-tax earnings to book equity,as a proxy for the direct costs of remunerating excess capital. However ROE is the ratio of post-tax earnings to equity capital. In the short run (when equity capital is exogenous) ROE is a measure of revenues rather than of costs. For comparability with previous studies we include ROE as a controlling variable, but we acknowledge that this reflects both revenue and cost effects. However the shortThe buffer capital model of Milne (2004) suggests that for financially strong banks this revenue impact will generate a negative relationship beween ROE and capital buffers, because a high level of earnings substitutes for capital as a buffer against unexpected shocks.

\footnotetext{
${ }^{4}$ Co-operative banks cannot issue new shares and members prefer cash payments over retained earnings because there is no market for their ownership claims.

${ }^{5}$ A negative output gap in a country with 10 percent trend growth may not be expected to cause a recession-deepening restriction on bank portfolios.

${ }^{6}$ We also investigated the use of the output gap which we obtained by applying the Hodrick-Prescott filter to the real GDP series. Estimates substituting this gap differed to only a minor extent and are therefore not presented here.
} 
We therefore expect to observe a negative relationship between the capital buffer and the $R O E$ variable.

The second cost is the cost of failure. Regulators constantly monitor banks' capital ratios $C$, ensuring that they do not fall below the regulatory minimum $C^{*}$ thus reducing the probability of bankruptcy and the costs associated with failure. ${ }^{7}$ Here, when $C=C^{*}$ the bank is faced with the option of recapitalizing or liquidating. Higher levels of capital therefore reduce the risk of non-compliance and the subsequent costs of failure which are directly proportional to absolute value of the negative net worth of the failing bank (Milne and Whalley, 2001).

The actual cost of failure can be considered as the loss of share value times the probability of failure. Since a banks' probability of failure is dependent on its risk profile, we proxy the cost of failure by adopting various measures of risk. As a first measure, we consider the ratio of non-performing loans to total loans (RISK) as in Ayuso et. al (2002). This is an ex post measure of the risks assumed by banks and is comparable to other measures adopted in the literature since banks with nonperforming loans are obliged to make provisions for loan losses. We further include an alternative measure for risk as per Stoltz and Wedow (2005) and Lindquist (2004) whereby we consider the ratio of new net provisions over total assets (RISK2). ${ }^{8}$ If banks set their capital in line with the true riskiness of their portfolios, then we would expect the relationship here to be positive. ${ }^{9}$

As discussed above there are several reasons, most notably greater portfolio diversification, for expecting a negative relationship between bank size and the level of capital buffers. We include a SIZE variable, the natural log of total assets, as a further measure of the cost of failure.

The final costs are the costs of capital adjustment. Considering financing under asymmetric information, costs in this sense are incurred when banks are forced to make use of external funds to add to existing internal capital (see for example Myers and Majluf, 1984). Such a cost mechanism provides motivation for holding higher levels of capital as a way of mitigating costs of remuneration. If the bank lets its internal funds fall too far, it is faced with the choice between cutting highly rewarding investments or incurring high costs of external finance. In order to capture these adjustment costs, we include the lagged dependent variable $B U F_{t-1}$. We follow Estrella (2004) by assuming the costs of adjusting capital are quadratic. With this specification higher adjustment costs would result in a higher coefficient of the lagged de-

\footnotetext{
${ }^{7}$ So called losses of failure include the loss of charter value, reputational loss, and the legal costs of the bankruptcy process. (see Ancharya, 1996).

${ }^{8}$ As the results for RISK are broadly in line with those obtained for RISK 2 , we present only those for RISK 2 for which a greater number of observations are available.

${ }^{9}$ Banks may vary significantly in their willingness to take risk. This measure therefore can be assumed to uncover information on bank type. Any further idiosyncratic time-invariant component in the banks risk profile would be captured by the $\mu_{i}$ component of the residual term of Equation 2 .
} 
pendent variable, signifying a slower speed of adjustment. We expect the coefficient to be positively signed.

In a further specification (model specification 2) we include some additional balance sheet variables, to further control for the determinants of bank capital. The size of a banks' profit can have an effect on bank capital in either a positive or a negative fashion but are considered an important source of capital financing, affecting the cost of adjustment. Since retained earnings are usually employed as a means to increase the capital cushion, a positive relationship would be evident. High profits on the other hand can similarly reflect high contract values and hence the need to consistently generate high profits. Consequently, capital buffers are increased through retained earnings implying a negative relationship between the buffer and the generation of profits (see Whalley and Milne, 2001). We therefore include post tax profits over total assets a measure of PROFIT with an ambiguous anticipated sign.

Finally, we further include the level of bank loans (NET LOANS) which acts to further reflect the risk profile of the bank since banks themselves could vary their capital buffers according to the risk profile of their loan portfolio. A larger number of loans with respect to total assets are likelier to reflect a riskier profile; the expected sign is therefore positive. We additionally incorporate annual loan growth $(\triangle L O A N)$ as a proxy for credit demand (Ayuso et al., 2004). Despite this variable being the interaction between credit supply and demand, it nevertheless serves as a proxy for credit demand since the main potential credit supply constraint (the capital requirements) is not binding in our sample. i.e. capital buffers are always positive. Moreover, since an increase in loan supply implies an increase in capital requirements, which in a context whereby the adjustment of capital $\left(B U F_{t-1}\right)$ is costly, is likely to result in an increase in capital buffers.

\section{Specification and Estimation Results}

Following previous literature (including Ayuso et al., 2004; Estrella, 2004), we test the hypotheses detailed in Section 2 through the use of a partial adjustment framework, where banks adjust capital towards a desired optimum capital buffers. The specification takes the following form:

$$
\Delta B U F_{i j t}=\delta\left(B U F_{i j t}^{*}-B U F_{i j t-1}\right)+u_{i j t}
$$

Here $i=1,2 \ldots N$ is an index of countries $j=1,2 \ldots J_{i}$ and index of banks within each country and $t=1,2, \ldots, T_{j_{i}}$ is the index of time observation for bank $j$ in country $i . u_{i j t}$ is the error term that can be decomposed as the sum of two components, a random country specific component $\mu_{i}$, plus a pure bank idiosyncratic component $\varepsilon_{i j t}$. 
$B U F_{i j t}\left(B U F_{i j t}^{*}\right)$ is equal to the (optimum) capital buffer of bank $i$ in country $j$ at time $t$. The proportionate adjustment towards the desired capital buffer in each period here is captured by $\delta$. If $\delta=1$, then adjustment is instantaneous while if $\delta=0$ then there is no adjustment.

$B U F_{i j t}^{*}$ however cannot be observed, and is therefore approximated by the various cost and revenue variables discussed in the previous section. ${ }^{10}$ The empirical model to be tested therefore becomes:

$$
B U F_{i j t}=\alpha K K_{i j t}+\gamma K F_{i j t}+(1-\delta) B U F_{i j t-1}+\beta C Y C L E_{t}+u_{i j t}
$$

Here $K K_{i t}, K F_{i t}$ and denote the cost of holding capital and the cost of failure as discussed in Section 2. The reported coefficients on the lagged dependent variable are estimates of $1-\delta$ i.e. the closer the estimated coefficient on the lagged dependent variable is to 0 the faster the speed of adjustment

Since we estimate dynamic models, including the lagged endogenous variable, we employ the two-step generalized method of moments (GMM) procedure of Arellano and Bond (1991) estimator. The methodology assumes no autocorrelation in the $u_{i j t}$ and uses the entire set of lagged $B U F_{i t}$ as instruments. We also include two to four lags of our other principal explanatory variables (RISK and ROE) as instruments in order to avoid correlation with $u_{i j t}$. The number of instruments chosen in each model was the largest possible, for which the Sargan J-statistic for overidentification restrictions was still satisfied. We additionally apply the Newey-West correction for heteroskedasticity and autocorrelation consistent covariances to further adjust the t-values for additional heteroskedasticity and autocorrelation.

\section{Estimation results for country groups.}

We estimate two variations of our model. The results are presented in Table 5 for the total EU25 sample and our five sub-sample country groups. Our first model (labelled model specification 1) employs ROE, RISK, and SIZE , as controls for the costs of capital management. Estimation results are presented with both the domestic and the broad cycle (EU25) measures of the output gap.

For the case of the EU25, EU15, EA and DK,SE,UK samples, we find a negative significant relationship between the capital buffer and each of the output gap variables. These findings support our $H_{1}(a)$ hypothesis of negative cyclical comovements in capital. The largest effect is seen for the DK,SE,UK sample, where the capital buffer decreases on average around 0.45 percentage points on a one percentage point rise in the domestic cyclical variable.

\footnotetext{
${ }^{10}$ For a theoretical derivation and explanation of linear-quadratic partial adjustment in models of bank capital see Ayuso et al. 2004 or Estrella, 2004.
} 
These findings are broadly in line with previous literature. Ayuso et al. (2004) Lindqvist (2004) and Stoltz and Wedow (2005) find a similar negative relationship between bank buffers and the cycle variables for German, Spanish and Norwegian banks respectively. These findings can additionally be compared to those of Bikker and Metzemakers who conduct a cross-country analysis of bank capital buffers for 29 OECD countries. Their OECD sample can in some respects be considered to be similar to our EU25 sample in that it includes both RAM10 and original member state countries. While they do uncover a negative relationship, they find that cyclical effects are fairly limited.

The RAM10 sample returns opposite results. Here we find a significant positive relationship between the buffer and the cycle variables. This finding is in line with our $H_{1}(b)$ hypothesis of pro-cyclicality and would tend to suggest forward-looking or prudent bank behaviour. Here we see a significant decrease in the capital buffer variable of 0.10 and 0.25 percentage points for a one percentage point rise in the domestic and the broad output gap respectively.

The coefficient on $R O E$, our proxy for the cost of capital, returns a significant negative coefficient, as expected, in each of the sub-sample estimations. The coefficients are essentially uniform across sub-groups, suggesting that the direct effects of such costs on bank capital are similar between European countries.

RISK2 (loan loss provisions over total lending) is highly significant and positive for four of the five sub-samples. This suggests that banks with relatively risky portfolios generally do hold more capital For the case of DK,SE,UK, the RISK 2 coefficients are negative and significant. This counterintuitive finding is in line with some of the other literature in this field (Ayuso et al., 2004; Lindqvist, 2005).

The SIZE coefficients are consistently and significantly negative. This finding is as expected and consistent with several explanations of buffer capital. Larger banks may hold less capital because they anticipate state support (the 'too big to fail hypothesis'). This finding is also consistent with the presence of scale economies in screening and monitoring, i.e. larger banks are more transparent, can access capital markets with less cost, and therefore require less excess capital held as insurance against risk. Finally, the negative SIZE coefficient is consistent with the notion that smaller banks are less diversified than their larger counterparts and therefore hold higher levels of buffer capital. The SIZE coefficients are generally uniform across sub-groups with slightly larger coefficients for the RAM10 countries.

Finally, the cost of adjusting capital, captured by the lagged endogenous variable, is positive and significant in almost all cases. This finding is in line with the view that the costs of capital adjustment are an important explanation of the holding of large capital buffers. The coefficients are largely uniform across sub-samples, which would indicate that the costs of adjustment are largely consistent between countries, corresponding to a rate of adjustment towards desired capital of around 66 percent per annum. However we find that the coefficients are negative for the DK, SE, UK sub-sample, which is inconsistent with a costly adjustment model of bank capital management. 
Table 5 presents further estimation results for a second model (model specification 2), adding several further balance sheet variables to our baseline model (model specification 1). Our principal finding here is that the inclusion of these additional variables, leaves the relationship between the output gap and bank capital buffers largely unchanged. Both the domestic and the broad output gap remain negatively related to the buffer variable in the EU25, EU15, EA and DK,SE,UK sub-samples. The effect continues to be largest for the DK,SE,UK sub-sample predicting that a one percentage point fall in either the domestic or the broad output gap would result in a 0.77 and 0.61 percentage points fall in desired capital. Similarly for the RAM10 banks, the relationship between the capital buffer and the cycle remains positive and significant. These findings confirm the robustness of the results obtained via the estimation of the baseline model above.

The coefficient on the proxy for the cost of holding capital ( $R O E$ ) and the speed of adjustment (the coefficient on the lagged dependent variable) are also broadly unchanged from those reported for model specification 1 . The coefficients for the RISK proxies are now larger while the coefficient on the SIZE variable is smaller and no longer significant. For the DK,SE,UK and RAM10 sub-samples the coefficient has become positive and significant.

The new PROFIT variable for all sub-samples is positive and highly significant; indicating that retained earnings seem to be used to increase the capital cushion. The effect is noticeably larger for the EA sample when compared to the other subsamples. The expected negative sign for the NET LOANS variable is found for the EU15, EA and RAM10 sub-samples, however the coefficients are broadly insignificant. The DK,SE,UK sample returns a highly significant positive coefficient. Considering the $\triangle L O A N$ variable, for all sub-samples, we find the parameter to be highly significant, with a negative sign as expected. This finding suggests that a contemporaneous increase in loan demand substantially reduces the capital buffer.

We have estimated a variety of other specifications, including subsets of the explanatory variables reported in Table 5 . In all cases the relationship between the capital buffer and the output gap is very similar to that which we report here, and hence these results are not reported.

Estimation results for sub-groups of types and sizes of banks.

Table 6 reports further versions of these estimation results, for sub-groups of banks, distinguishing commercial, savings and co-operative banks and also large and small banks. We report estimates only for the EA15. This is because the RAM10 subsample consists only of small commercial banks and RAM10 banks appear to behave so differently from those in the EA15. Considering commercial and savings banks, we find that for savings banks the co-movement with the cycle remains negative, but for co-operative banks the relationship is very different with a positive relationship evident between the cycle and capital buffers. The results for savings banks are more significant than for commercial banks, suggesting that the negative relationship reported in Table 5 is largely driven by savings banks. 
This finding can help explain the relationship between our results and those of other researchers. Stoltz and Wedow (2005) present evidence for German banks showing that the relationship between the buffer and the cycle variable is stronger for savings banks than it is for co-operatives. The cross-country study of Bikker and Metzemakers (2004) finds that the cyclical effects appear to be limited. This finding is in line with our results since they focus their estimations on commercial banks only. Ayuso et al. (2004) consider only savings and commercial banks in their study and find a robustly significant negative relationship. Their study does not however analyse bank type effects separately.

The ROE variable coefficients are very similar to those reported in Table 5. The coefficient is noticeably more significant amongst savings banks than it is for cooperative or commercial banks. This finding tends to indicate that the cost of holding excess capital appears to be most significant for co-operative banks when compared to savings and commercial banks.

The RISK coefficient remains positive and significant for both commercial and co-operative banks in all three sub-samples, while it is negative for savings banks. The sizes of the coefficients are notably larger for co-operative banks. The SIZE variables are negative and significant for co-operative banks while they are largely insignificant for the other bank types.

For all three sub-samples, the $B U F_{t-1}$ variable is positive and highly significant for commercial banks, while it is very small (and significant) for savings banks and insignificant for co-operative banks. This suggests that adjustment costs are most important for commercial banks.

Turning to the comparison by bank size, also reported in Table 6, a positive and significant relationship appears to exist between the capital buffers of small banks and output gap variables, while the relationship is negative and significant for large banks. The coefficients on the ROE variable are little changed from those obtained for the initial total sample estimations. The coefficients are negative and highly significant for both small and large banks.

The RISK coefficients remain positive and significant for both small and large banks, while the coefficients vary for the SIZE variables. For small banks we find positive and significant coefficients, while the coefficients for large banks are negative and significant. Taken together these results suggest a hump shaped relationship with the largest capital buffers found amongst middle sized banks. This is in line with the hypothesis that the very largest banks generally feel themselves protected by the government safety net as per the 'too-big-to-fail' hypothesis. These results warrant further investigation.

The estimated cost of adjusting capital (the coefficient on $B U F_{t-1}$ ) is significant for both large and small banks. The coefficient is somewhat lower for small banks suggesting that adjustment costs play a larger role in the case of large banks.

To summarise, our estimations by both size and type of bank provide evidence that the capital buffers of both small and co-operative banks tend to have a positive 
relationship with the output gap variables. On the other hand we find negative comovement with the cycle for commercial banks, savings banks, and large banks. These differential results might be due to different access to capital markets or due to the fact both smaller banks as well as cooperative banks are more reliant on retained earnings than other banks in the sample hence building up capital during the economic upturn.

\section{Robustness tests.}

In order to complete our analysis, we conducted several further alternative estimations as a check on the robustness of our main findings. Since they do not alter the reported relationship between buffer capital and the business cycle, these estimation results are not reported here, but are available from the authors.

Our model incorporates several jointly determined variables. The issue then arises whether the reduced form relationships that we have reported beween capital buffers and the business cycle are robust to alternative dynamic specifications. To investigate this we have also estimated a static version of the model where we omit the lagged dependent variable $B U F_{t-1}$. We also experimented with varying lag lengths for the explanatory variables, and by dropping of the $R O E$ variable from the estimations altogether. In all cases the coefficients on teh business cycle variables remain very close to our reported results, indicating that these estimates are reasonably robust to dynamic respecification.

There are potentially individual national effects that could arise from various country-specific characteristics relating to the legal, regulatory, structural, or tax and accounting framework. A simple way to test, and control for these conditions, is to create a country-specific dummy variable $\left(D_{i}\right)$ for each country. As it turns out, there are no significant fixed country dummy variables in our regressions, indicating that all the national effects are already captured by our chosen specifications.

We re-estimated our model, including both the broad and the domestic cycle components among the regressors. The idea here is that the domestic cycle could capture dynamic national effects that are not depicted by the broad EU25 cycle. We would expect this effect to be particularly relevant for those countries outside EMU that, in principle, are more likely to have a business cycle dynamics different from the core EMU countries ${ }^{11}$. We find that for both the DK,SE, UK and the RAM10 samples, we are able to detect significant additional effects from the domestic cycle variable, indicating that national effects beyond those captured by the individual country dummies exists. In the case of the DK,SE,UK and the RAM10 country grouping, we find that both the EU25 and the domestic cycle are significant at the five percent level.

\footnotetext{
${ }^{11}$ We start by calculating correlations between both the individual cycle and the sub-group cycle in order to investigate whether multicollinearity affects our estimations. As all coefficients are significantly below one, we can proceed without further work. For brevity, correlations between variables are not presented here but are available from the authors on request.
} 
This suggests that national effects, as captured by the individual country business cycle variables, are important for the countries making up the DK, SE, UK and RAM10 sub-samples. These effects appear to have a significant impact on the movements and fluctuations of capital buffers of these countries ${ }^{12}$.

Finally we have been concerned with a further econometric problem affecting all studies, such as our own, that combine macro-level and micro-data, whether in panel or cross-section. This problem, originally highlighted by Moulton (1990), is the possibility of a substantial downward bias on standard errors for macro-economic variables, when there is clustering of unobserved random variables. This possibility cannot be ignored since any omission of macro-economic variables, affecting the dependent variable, will lead to such clustering.

\section{Conclusions}

This paper examines the relationship that exists between European bank capital buffer fluctuations and business cycle variations over the last eight years. Much of the empirical literature in this field has focussed on examining the determinants of bank capitalization within a single country. Our research is cross-country and centred on the comparison of different sub-sample groups of countries.

We build an unbalanced panel of 486 banks, using annual balance sheet data between 1997 and 2004. Controlling for various probable determinants of capital buffer movements, we analyse the remaining impact that the cycle variables appear to have. We find that for the EU25, EU15, EA and DK,SE,UK sub-samples, a significant negative relationship between the capital buffers of banks and the output gap exists. This finding is in line with the existing literature in this field and provides further cause for concern relating to the potential 'pro-cyclical' impact that the introduction of the new Accord will have on the amplification of the business cycle. For the RAM10 banks i.e. those in the 10 accession countries that joined the EU in 2004, our results indicate that capital buffers co-move positively with the output gap. The results suggest that the introduction of Basel II might have a stronger impact on capital management in the EU15 countries than in the RAM10.

We further break the sample down, distinguishing between both type and size of bank. Our findings indicate that capital buffers of large banks, and of commercial and savings banks, appear to behave in a similar fashion to the sample as a whole, co-moving negatively with the output gap i.e. declining in recession. On the other hand the capital buffers of small banks and of co-operative banks co-move positively with the cycle, rising in recession. These differential results might be due to different access to capital markets or due to the fact that these banks are more reliant on

\footnotetext{
${ }^{12}$ We additionally experiment by substituting the broad cycle with the difference between the domestic cycle and the broad cycle. The results are largely unchanged with those obtained using the domestic and the broad cycle together.
} 
retained earnings than other banks in the sample hence building up capital during the economic upturn.

While these results are striking, they are limited by the restricted data available. Furthermore, as indicated by Figure 2, it is apparent that much of the buffer movements of the RAM10 banks have occurred during the first half of the sample period. Therefore, when more data on these countries becomes available, further research into the degree to which capital buffer decisions of RAM10 are converging to become more like the other EU members would be beneficial.

\section{References}

Alfon, I., Argimón, I. and Bascuňana-Ambrós, P. (2004) "What Determines How Much Capital Is Held By UK Banks and Building Societies" London: FSA Occasional Paper No. 22.

Ancharya, S. (1996) "Charter Value, Minimum Bank Capital Requirements and Deposit Insurance Pricing in Equilibrium" Journal of Banking and Finance, 20, pp. 351-375.

Ayuso, J., Pérez, D. and Saurina, J. (2004) "Are Capital Buffers Pro-Cyclical? Evidence from Spanish Panel Data" Journal of Financial Intermediation, 13, pp. 249-264.

Bank for International Settlements (BIS). (2002) "Quantitative Impact Study, 3."

Basel Committee on Banking Supervision (BCBS), (2001). "Review of Procyclicality." Mimeo, Research Task Force.

Berger, A., Udell, G. (1994) "Did Risk-Based Capital Allocated Bank Credit Cause a 'Credit Crunch' in the United States?" Journal of Money, Credit and Banking, 26(3), pp. 227-308.

Berger, A. (1995) "The Relationship Between Capital and Earnings in Banking" Journal of Money, Credit and Banking, 27(2).

Berger, A., Herring, R. and Szegö, G. (1995) "The Role of Capital in Financial Institutions." Journal of Banking and Finance, 19 pp. 393-430.

Bikker, J. and Metzemakers, P. (2004) "Is Bank Capital Procyclical? A Cross-Country Analysis" De Nederlandsche Bank Working Paper 009/2004.

Borio, C., Furfine, C. and Lowe, P. (2001) "Procyclicality of the Financial System and the Financial Stability: Issues and Policy Options." Bank for International Settlements Working Paper No.1, pp. 1-57.

Campbell, T. (1979) "Optimal Investment Financing Decisions and the Value of Confidentiality." Journal of Financial Quantitative Analysis, 14 pp. 913-924.

Crocket, A. (2001) "Market Discipline and Financial Stability." In: Financial Stability Review, Bank of England, pp. 166-73. 
Daníelsson, J., Embrechts, P., Goodhart, C., Keating, C., Muennich, F., Renault, O., Song Shin, H. (2001). "An Academic Response to Basel II." Special Paper 130. Financial Markets Group, London School of Economics.

Dewatripont, M. and Tirole, J. (1993) "The Prudential Regulation of Banks" MIT Press.

DNB. (2001) "Towards a New Basel Capital Accord" Quarterly Bulletin, 48-54.

ECB. (2001) "The New Capital Adequacy Regime: The ECB Perspective." Monthly Bulletin, May, 59-74.

Ediz, T., Michal, I. and Perraudin, W. (1998) "The Impact of Capital Requirements on UK Bank Behaviour." FRBNY Economic Policy Review.

Estrella, A. (2004) "The Cyclical Behaviour of Optimal Bank Capital." Journal of Banking and Finance, 28(6), pp.1469-1498.

Estt, B. (1997) "Organizational Form and Risk Taking in the Savings and Loan Industry." Journal of Financial Economics, 44, pp. 25-55.

Freixas, X. and Rochet, J (1997) "The Microeconomics of Banking." Dryden Press.

Furfine, C. (2000) "Evidence on the Response of US Banks to Changes in Capital Requirements." Bank for International Settlements Working Paper No.88.

Gorton, G. and Rosen, R. (1995) "Corporate Control, Portfolio Choice, and the Decline of Banking." The Journal of Finance, 50(5), pp. 1377-1400.

Greenbaum, S. and Thakor, A. (1995) "Contemporary Financial Intermediation." MIT Press.

Jackson, P. (1999) "Capital Requirements and Bank Behaviour: The Impact of the Basel Accord." Basel Committee on Banking Supervision, Working Paper No.1.

Keeley, M. (1990) "Deposit Insurance, Risk and Market Power in Banking?" American Economic Review 80, pp. 1183-1200.

Kwan, S. and Eisenbeis, R. (1997) "Bank, Risk, Capitalization, and Operating Efficiency." Journal of Financial Services Research 12, pp. 1183-1200.

Lindquist, K. (2004) "Banks' Buffer Capital: How Important is Risk?" Journal of International Money and Finance 23(3), pp. 493-513.

Marcus, A. (1984) "Deregulation and Bank Financial Policy." Journal of Banking and Finance, 8, pp. 557-565.

Milgrom, P. and Roberts, J. (1992) "Economics, Organization and Management." Englewood Cliffs, N.J.: Apprentice Hall.

Milne, A. (2004) "The Inventory Perspective on Bank Capital." SSRN..

Milne, A. and Wiley, E. (2001) "Bank Capital Regulation and Incentives for Risk -Taking." SSRN.

Mishkin, F. (2000) "The Economics of Money, Banking and Financial Markets" $6^{\text {th }}$ Edition, Addison Wesley Longman. 
Moulton, B. (1990) "An Illustration of a Pitfall in Estimating the Effects of Aggregate Variables on Micro Units." The Review of Economics and Statistics, 72(2), pp. 334-338.

Myers, S. and Majluf, N (1984) "Corporate Financing and Investment Decisions When Firms Have Information That Investors Do Not" Journal of Financial Economics, 13, pp. 187-222.

Peura, S. and Jokivuolle, E (2004) "Simulation Based Stress Tests of Banks' Regulatory Capital" Journal of Banking and Finance, 28(8), pp. 1801-1824.

Rajan, R. (1994) "Why Bank Credit Policies Fluctuate: A Theory and Some Evidence." Quarterly Journal of Economics, CIX(2), pp. 399-441.

Rime, B. (2001) "Capital Requirements and Bank Behaviour: Empirical Evidence for Switzerland." Journal of Banking and Finance, 25, pp. 1137-1178.

Rochet, J. (1992) "Capital Requirements and the Behaviour of Commercial Banks." European Economic Review, 36 pp. 1137-1178.

Saounders, A., Strock, E., and Travlos, N. (1990) "Ownership Structure, Deregulation and Bank Risk Taking." The Journal of Finance, 45 pp. 643-654.

Salas, V. and Saurina, J. (2002b) "Credit Risk in Two Institutional Regimes: Spanish Commercial and Savings Banks." Deutsch Journal of Financial Services Rsearch, 22(3), pp. 203-224.

Stoltz, S. and Wedow, M. (2005) "Banks' Regulatory Capital Buffer and the Business Cycle: Evidence for German Savings and Co-operative Banks." Deutsch Bundesbank Discussion Paper No. 07/2005. 
Table 1: Total Capital Buffers by Country (weighted by total assets)

\begin{tabular}{|lccccccccc|}
\hline & $\mathbf{1 9 9 7}$ & $\mathbf{1 9 9 8}$ & $\mathbf{1 9 9 9}$ & $\mathbf{2 0 0 0}$ & $\mathbf{2 0 0 1}$ & $\mathbf{2 0 0 2}$ & $\mathbf{2 0 0 3}$ & $\mathbf{2 0 0 4}$ & avg \\
\hline AT & 0.72 & 2.09 & 2.09 & 1.96 & 2.89 & 2.63 & 3.08 & 3.10 & 2.32 \\
BE & 3.43 & 3.45 & 4.37 & 5.75 & 5.31 & 5.06 & 4.66 & 4.45 & 4.56 \\
FI & 4.03 & 2.49 & 4.01 & 1.38 & 1.68 & 2.53 & 10.97 & 11.20 & 4.79 \\
FR & 2.24 & 2.31 & 2.13 & 1.80 & 1.78 & 1.67 & 1.84 & 1.49 & 1.91 \\
DE & 1.96 & 1.89 & 2.46 & 3.00 & 2.79 & 2.85 & 4.41 & 4.37 & 2.97 \\
GR & 1.73 & 1.67 & 6.21 & 4.51 & 2.83 & 2.24 & 3.42 & 4.57 & 3.40 \\
IE & 3.02 & 3.54 & 3.23 & 3.05 & 3.05 & 4.95 & 6.82 & 5.54 & 4.15 \\
IT & 1.49 & 1.81 & 1.46 & 1.61 & 1.34 & 2.32 & 2.42 & 2.87 & 1.92 \\
LU & 4.87 & 4.07 & 4.26 & 4.07 & 3.94 & 3.75 & 4.88 & 2.47 & 4.04 \\
NL & 2.96 & 2.84 & 2.71 & 2.69 & 2.80 & 3.23 & 3.56 & 3.50 & 3.04 \\
PT & 2.66 & 1.86 & 2.35 & 0.98 & 1.23 & 1.62 & 2.04 & 2.21 & 1.87 \\
ES & 1.93 & 2.75 & 2.39 & 2.50 & 3.20 & 2.82 & 2.63 & 2.51 & 2.59 \\
\hline DK & 2.29 & 2.22 & 2.62 & 1.75 & 2.24 & 2.43 & 2.79 & 2.23 & 2.32 \\
SE & 2.55 & 2.73 & 3.23 & 2.46 & 2.70 & 2.29 & 2.53 & 2.68 & 2.65 \\
UK & 1.70 & 1.47 & 1.89 & 2.37 & 1.50 & 0.96 & 0.92 & 0.85 & 1.46 \\
\hline & & & & & & & & & \\
\hline CY & 2.13 & 1.34 & 3.94 & 4.63 & 3.24 & 1.52 & 1.48 & 2.83 & 2.64 \\
CZ & 2.09 & 3.79 & 4.81 & 6.13 & 4.03 & 3.94 & 4.43 & 2.74 & 4.00 \\
EE & 3.23 & 8.57 & 10.55 & 7.53 & 6.84 & 6.55 & 5.18 & 4.01 & 6.56 \\
HU & 4.51 & 4.73 & 7.32 & 6.88 & 3.27 & 4.68 & 2.27 & 1.96 & 4.45 \\
LAT & 8.10 & 1.60 & 4.78 & 3.00 & 2.74 & 2.42 & 2.33 & 4.14 & 3.64 \\
LIT & 2.23 & 15.40 & 3.12 & 3.79 & 4.49 & 4.81 & 1.97 & 2.28 & 4.76 \\
MAL & 6.57 & 8.46 & 8.06 & 8.27 & 6.65 & 7.19 & 7.71 & 3.01 & 6.99 \\
PL & 2.32 & 2.18 & 4.84 & 5.36 & 6.33 & 5.67 & 5.76 & 7.67 & 5.02 \\
SLK & & & & & & 5.36 & 10.14 & 12.05 & 9.18 \\
SLV & 8.06 & 6.10 & 5.49 & 6.71 & 6.03 & 8.09 & 6.29 & 6.04 & 6.60 \\
\hline EU25 & 3.20 & 3.72 & 4.10 & 3.84 & 3.45 & 3.66 & 4.18 & 4.03 & 3.77 \\
EU15 & 2.51 & 2.48 & 3.03 & 2.66 & 2.62 & 2.76 & 3.80 & 3.60 & 2.93 \\
EA & 2.59 & 2.56 & 3.14 & 2.77 & 2.74 & 2.97 & 4.23 & 4.02 & 3.13 \\
DK,SE,UK & 2.18 & 2.14 & 2.58 & 2.19 & 2.15 & 1.90 & 2.08 & 1.92 & 2.14 \\
RAM10 & 4.36 & 5.80 & 5.88 & 5.81 & 4.85 & 5.02 & 4.75 & 4.67 & 5.14 \\
\hline
\end{tabular}

Note: $A T=$ Austria, $B E=$ Belgium, $D E=$ Germany, $E S=$ Spain, $F I=$ Finland, $F R=$ France, $G R=$ Greece, $I E=$ Ireland, $I T=$ Italy, $L U=$ Luxembourg, $N L=$ Netherlands, $P T=$ Portugal, $D K=$ Denmark, $S E=$ Sweden, $U K=$ United Kingdom, $C Y=$ Cyprus, $C Z=$ Czech Republic, $E E=$ Estonia, $H U=$ Hungary, $L A T=$ Latvia, $L I T=L i t h u a n i a$, $M A L=$ Malta, $P L=$ Poland, $S K=$ Slovakia, $S L=$ Slovenia .

* denotes figures equal to the un-weighted average of composite countries.

Capital buffer is defined as the institutions total risk weighted capital (Tier $2+$ Tier 2) capital less the required minimum of $8 \%$. Within each country we show average bank capital buffers weighted by bank market share. 
Table 2: National Total (Tier $1+$ Tier 2) Capital Requirements

\begin{tabular}{|l|ccl|}
\hline \multicolumn{4}{|c|}{ Countries Applying Ratio Above 8\% } \\
\hline & $\begin{array}{c}\text { minimum } \\
\text { required ratio }\end{array}$ & $\begin{array}{c}\text { year of } \\
\text { implementation }\end{array}$ & \multicolumn{1}{c|}{ reason } \\
UK & $9 \% *$ & 1979 & \\
& $8 \%$ & 1997 & Changes in market \\
& $10 \%$ & 2001 & structure \\
CZ & $8 \%$ & 1992 & Rapid growth of bank \\
EE & $10 \%$ & 1997 & assets and a change \\
& & & in operating \\
& & & environment \\
HU & $8 \%$ & 1991 & \\
LAT & $10 \%$ & 1997 & \\
& $8 \%$ & 2004 & \\
LIT & $10 \%$ & 1997 & \\
& $8 \%$ & 2005 & \\
MAL & $8 \%$ & 1994 & \\
PL & $8 \%$ & 1992 & \\
SK & $8 \%$ & 1997 & \\
SL & $8 \%$ & 2002 & \\
\hline
\end{tabular}

Note:* As explained in Appendix I, the FSA sets additional 'trigger' and 'higher target' ratios for UK banks resulting in higher levels of capital required by the regulators. For this reason in the study we apply a 9\% requirement to UK banks active in the sample and calculate the buffer as capital above this level.

$A T=$ Austria,$B E=$ Belgium,$D E=$ Germany,$E S=$ Spain,$F I=$ Finland,$F R=$ France,$G R=$ Greece $I E=$ Ireland, $I T=$ Italy, $L U=$ Luxembourg, $N L=$ Netherlands, $P T=$ Portugal, $D K=$ Denmark, $S E=$ Sweden, $U K=$ United Kingdom, $C Y=$ Cyprus, $C Z=$ Czech Republic, $E E=$ Estonia, $H U=$ Hungary, $L A T=$ Latvia, $L I T=$ Lithuania, $M A L=$ Malta, $P L=$ Poland, $S K=$ Slovakia, $S L=$ Slovenia . 
Table 3: Distribution of the Sample

\begin{tabular}{|c|c|c|c|c|c|c|}
\hline & $\begin{array}{c}\text { commercial } \\
\text { banks }\end{array}$ & $\begin{array}{c}\text { co-operative } \\
\text { banks }\end{array}$ & $\begin{array}{c}\text { savings } \\
\text { banks }\end{array}$ & $\begin{array}{c}\text { big banks } \\
\text { (total assets }>\text { EUR37 } \\
\text { billion in 2004) }\end{array}$ & $\begin{array}{c}\text { small banks } \\
\text { (total assets }<\text { EUR37 } \\
\text { billion in 2004) }\end{array}$ & total \\
\hline AT & 12 & 8 & 6 & 4 & 22 & 26 \\
\hline $\mathrm{BE}$ & 10 & & 2 & 2 & 10 & 12 \\
\hline ES & 23 & 3 & 44 & 8 & 62 & 70 \\
\hline FI & 4 & & 1 & 1 & 4 & 5 \\
\hline FR & 55 & 42 & 6 & 13 & 90 & 103 \\
\hline $\mathrm{DE}$ & 24 & 8 & 2 & 7 & 27 & 34 \\
\hline GR & 12 & & & 1 & 11 & 12 \\
\hline IE & 11 & & & 4 & 7 & 11 \\
\hline IT & 30 & 13 & 11 & 10 & 44 & 54 \\
\hline LU & 7 & & & 1 & 6 & 7 \\
\hline NL & 18 & 1 & & 5 & 14 & 19 \\
\hline PT & 8 & 1 & 2 & 3 & 8 & 11 \\
\hline DK & 13 & & 2 & 5 & 9 & 15 \\
\hline SE & 3 & 1 & 2 & 5 & 1 & 6 \\
\hline UK & 41 & & 1 & 9 & 33 & 42 \\
\hline $\mathrm{CY}$ & 5 & & & & 5 & 5 \\
\hline $\mathrm{CZ}$ & 3 & & & & 3 & 3 \\
\hline EE & 2 & & & & 2 & 2 \\
\hline $\mathrm{HU}$ & 6 & & & & 6 & 6 \\
\hline LAT & 4 & & & & 4 & 4 \\
\hline LIT & 2 & & & & 2 & 2 \\
\hline MAL & 2 & & & & 2 & 2 \\
\hline PL & 9 & & 1 & 5 & 5 & 10 \\
\hline SK & 2 & & & 1 & 1 & 2 \\
\hline SLOV & 5 & & & & 5 & 5 \\
\hline EU25 & 311 & 77 & 80 & 85 & 383 & 468 \\
\hline EU15 & 271 & 77 & 79 & 79 & 348 & 427 \\
\hline EA & 214 & 76 & 74 & 59 & 305 & 364 \\
\hline DK,SE,UK & 57 & 1 & 5 & 20 & 43 & 63 \\
\hline RAM10 & 40 & 0 & 1 & 6 & 35 & 41 \\
\hline
\end{tabular}

Table 4: Description of Variables Adopted

\begin{tabular}{|c|c|}
\hline Variable & Description \\
\hline Balance sheet variables & \\
\hline
\end{tabular}




\begin{tabular}{|l|l|}
\hline buf & Total capital-national regulatory minimum as per table 2 \\
roe & return on equity \\
risk & ratio of non-performing loans to total loans \\
risk2 & loan-loss provisions over total assets \\
size & log of total assets \\
profit & post-tax profit over total assets \\
Dloan & annual loan growth \\
net loans & loans over total assets \\
\hline Business and economic cycle variables \\
\hline gdp & domestic and sub-sample GDP growth \\
output gap & HP filtered real GDP series \\
\hline
\end{tabular}

Figure 1: Capital Buffer Development by Sub-Sample

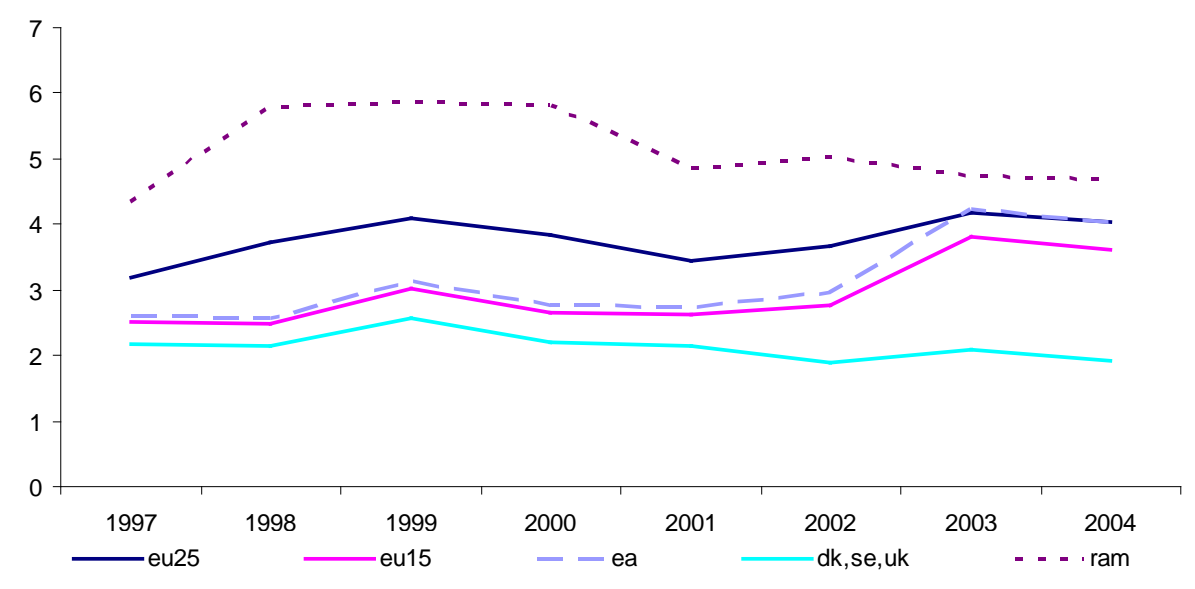


Figure 2: Capital Buffers by Bank Type and Size (Weighted by Total Assets)

EU25

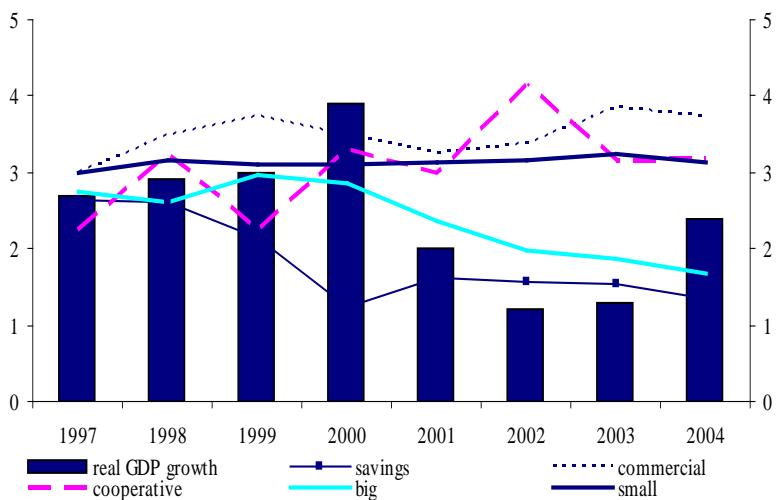

EA

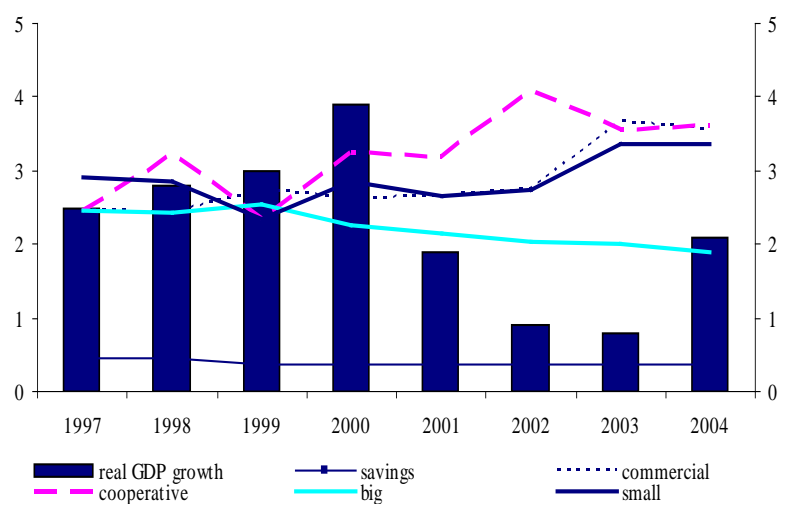

RAM10

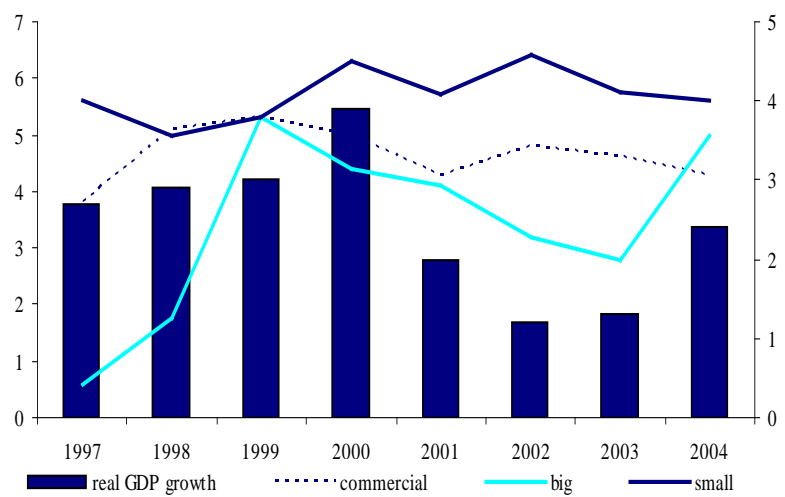

Note: Capital buffer is defined as the institutions total capital less the required minimum.
EU15

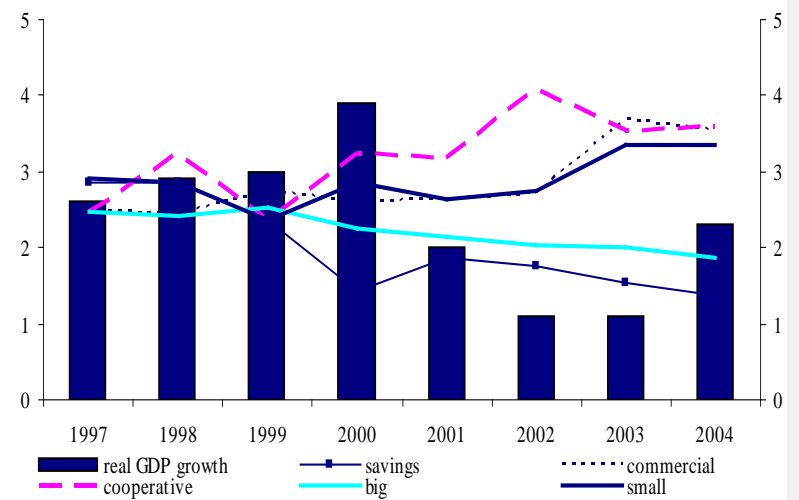

DK,SE,UK

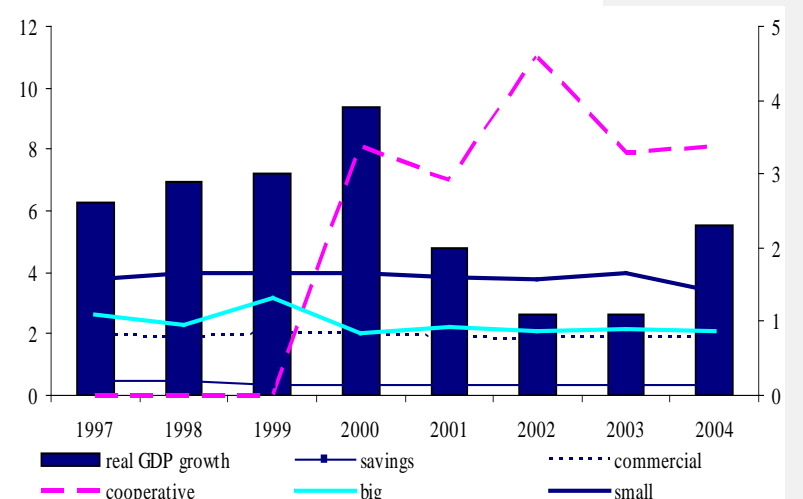


Table 5: Two-Step GMM Estimates

\begin{tabular}{|c|c|c|c|c|c|c|c|c|c|c|c|c|}
\hline \multirow[b]{3}{*}{ Cycle variable: } & \multicolumn{4}{|c|}{ EU25 } & \multicolumn{4}{|c|}{ EU15 } & \multicolumn{4}{|c|}{ EA } \\
\hline & \multicolumn{2}{|c|}{ Model Specification 1} & \multicolumn{2}{|c|}{ Model Specification 2} & \multicolumn{2}{|c|}{ Model Specification 1} & \multicolumn{2}{|c|}{ Model Specification 2} & \multicolumn{2}{|c|}{ Model Specification 1} & \multicolumn{2}{|c|}{ Model Specification 2} \\
\hline & $\begin{array}{l}\text { domestic } \\
\text { cycle }\end{array}$ & EU25 cycle & $\begin{array}{l}\text { domestic } \\
\text { cycle }\end{array}$ & EU25 cycle & $\begin{array}{l}\text { domestic } \\
\text { cycle }\end{array}$ & EU15 cycle & $\begin{array}{c}\text { domestic } \\
\text { cycle }\end{array}$ & EU15 cycle & $\begin{array}{l}\text { domestic } \\
\text { cycle }\end{array}$ & EA cycle & $\begin{array}{l}\text { domestic } \\
\text { cycle }\end{array}$ & EA cycle \\
\hline$b u f_{t-1}$ & $\begin{array}{c}0.33 \\
(4.22) * * *\end{array}$ & $\begin{array}{c}0.41 \\
(4.62)^{* * *}\end{array}$ & $\begin{array}{c}0.28 \\
(3.66) * * *\end{array}$ & $\begin{array}{c}0.24 \\
(5.82) * * *\end{array}$ & $\begin{array}{c}0.18 \\
(2.91)^{* * *}\end{array}$ & $\begin{array}{c}0.18 \\
(3.02)^{* * *}\end{array}$ & $\begin{array}{c}0.33 \\
(3.51)^{* * *}\end{array}$ & $\begin{array}{c}0.25 \\
(3.24)^{* * * *}\end{array}$ & $\begin{array}{c}0.14 \\
(3.12)^{* * *}\end{array}$ & $\begin{array}{c}0.21 \\
(3.62)^{* * * *}\end{array}$ & $\begin{array}{c}0.19 \\
(4.62)^{* * *}\end{array}$ & $\begin{array}{c}0.21 \\
(3.76) * * *\end{array}$ \\
\hline roe & -0.03 & -0.04 & -0.03 & -0.03 & -0.04 & -0.05 & -0.05 & -0.04 & -0.03 & -0.05 & -0.04 & -0.05 \\
\hline . & $\begin{array}{l}(1.85)^{*} \\
6455\end{array}$ & $(1.66)^{*}$ & $(1.81)^{* *}$ & $\begin{array}{l}(1.31)^{*} \\
72.33\end{array}$ & $(5.41)^{* * *}$ & $(3.43) * * *$ & $\begin{array}{l}(1.97) * \\
35.86\end{array}$ & $\begin{array}{l}(2.35) * * \\
66.97\end{array}$ & $(1.75)^{* *}$ & $\begin{array}{l}(1.23)^{*} \\
37.62\end{array}$ & $\begin{array}{l}(1.05) \\
5524\end{array}$ & $\begin{array}{l}(1.16) \\
2367\end{array}$ \\
\hline risk & $\begin{array}{l}64.55 \\
(4.33)^{* * *}\end{array}$ & $\begin{array}{l}62.75 \\
(3.55)^{* * *}\end{array}$ & $\begin{array}{l}76.44 \\
(3.54)^{* * * *}\end{array}$ & $\begin{array}{l}72.33 \\
(3.17)^{* * *}\end{array}$ & $\begin{array}{l}44.66 \\
(3.16)^{* * *}\end{array}$ & $\begin{array}{l}43.72 \\
(2.18)^{* *}\end{array}$ & $\begin{array}{l}35.86 \\
(5.02) * * *\end{array}$ & $\begin{array}{l}66.97 \\
(4.87)^{* * *}\end{array}$ & $\begin{array}{l}42.11 \\
(3.12) * * *\end{array}$ & $\begin{array}{l}37.62 \\
(2.42)^{* *}\end{array}$ & $\begin{array}{l}55.24 \\
(4.22)^{* * *}\end{array}$ & $\begin{array}{l}23.67 \\
(3.96)^{* * *}\end{array}$ \\
\hline size & $\begin{array}{l}-3.97 \\
(6.33)^{* * *}\end{array}$ & $\begin{array}{l}-4.99 \\
585 * * *\end{array}$ & -3.62 & -4.12 & -3.25 & -3.69 & -0.97 & -5.47 & -4.46 & -4.25 & 0.55 & -0.21 \\
\hline profit & & & 180.10 & 175.22 & & & 165.21 & 135.21 & & (0.00) & 152.55 & 164.75 \\
\hline culo & -0.10 & & $\begin{array}{l}(3.56) * * * \\
-0.06\end{array}$ & $\begin{array}{l}(3.02) * * * \\
-0.02\end{array}$ & & & $\begin{array}{l}(3.99) * * * \\
-0.08\end{array}$ & $\begin{array}{l}(3.42)^{* * *} \\
-0.41\end{array}$ & & & $(3.11)^{* * *}$ & $(3.75) * * *$ \\
\hline cycle & $\left(3.777^{* * * *}\right.$ & $\begin{array}{l}-0.03 \\
(3.22) * *\end{array}$ & $\begin{array}{l}-0.06 \\
(3.98) * * *\end{array}$ & $\begin{array}{l}-0.02 \\
(3.01)^{* * *}\end{array}$ & $\begin{array}{l}-0.12 \\
(4.99)^{* * *}\end{array}$ & $\begin{array}{l}-0.12 \\
(4.65)^{* * *}\end{array}$ & $\begin{array}{c}-0.08 \\
(4.01) * * *\end{array}$ & $\begin{array}{c}-0.41 \\
(3.33) * * *\end{array}$ & $\begin{array}{l}-0.13 \\
(3.66)^{* * *}\end{array}$ & $\begin{array}{l}-0.15 \\
(5.02)^{* * *}\end{array}$ & $\begin{array}{c}-0.04 \\
(3.11)^{* * *}\end{array}$ & $\begin{array}{l}-0.10 \\
(2.98)^{* * *}\end{array}$ \\
\hline Dloan & & & -0.01 & -0.01 & & & -0.01 & -0.00 & & & -0.02 & -0.02 \\
\hline net loans & & & -0.06 & -0.06 & & & -0.11 & -0.01 & & & -0.00 & -0.01 \\
\hline & & & $(0.98)$ & $(0.76)$ & & & $(1.02)$ & $(0.63)$ & & & $(0.72)$ & $(0.99)$ \\
\hline Sargan & $21.34(0.74)$ & $20.58(0.67)$ & $24.68(0.88)$ & $27.69(0.76)$ & $20.97(0.69)$ & $24.79(0.78)$ & $27.69(0.99)$ & $29.78(0.92)$ & $25.78(0.76)$ & $21.69(0.59)$ & $27.63(0.79)$ & $22.46(0.83)$ \\
\hline$a(1)$ & $-2.16(0.00)$ & $-2.78(0.00)$ & $-2.34(0.00)$ & $-2.65(0.00)$ & $-2.02(0.00)$ & $-2.76(0.00)$ & $-2.42(0.00)$ & $-2.36(0.00)$ & $-2.45(0.00)$ & $-2.62(0.00)$ & $-2.09(0.00)$ & $-2.11(0.00)$ \\
\hline$a(2)$ & $-1.56(0.72)$ & $-1.69(0.44)$ & $-1.11(0.46)$ & $-0.84(0.36)$ & $-1.04(0.52)$ & $-1.33(0.96)$ & $-1.42(0.45)$ & $-1.29(0.65)$ & $-1.65(0.44)$ & $-0.95(0.52)$ & $-1.08(0.46)$ & $-1.12(0.76)$ \\
\hline
\end{tabular}

Note: Dependent variable is $B U F_{i t}$. Other variables as defined in Table 3.

$T$-values presented in parentheses. $a(1)$ and $a(2)$ represent first and second order residual tests.

$*, * *, * * *$ denote significance at the ten, five and one percent levels of significance respectively.

Cycle variable corresponds to real GDP growth. Models including the broad and the sub-group cycle are estimated separately. 
Table 5 (continued): Two-Step GMM Estimates

\begin{tabular}{|c|c|c|c|c|c|c|c|c|}
\hline \multirow[b]{3}{*}{ Cycle variable: } & \multicolumn{4}{|c|}{ DK,SE,UK } & \multicolumn{4}{|c|}{ RAM10 } \\
\hline & \multicolumn{2}{|c|}{ Model Specification 1} & \multicolumn{2}{|c|}{ Model Specification 2} & \multicolumn{2}{|c|}{ Model Specification 1} & \multicolumn{2}{|c|}{ Model Specification 2} \\
\hline & $\begin{array}{l}\text { domestic } \\
\text { cycle }\end{array}$ & $\begin{array}{l}\text { EU15 } \\
\text { cycle }\end{array}$ & $\begin{array}{l}\text { domestic } \\
\text { cycle }\end{array}$ & $\begin{array}{l}\text { EU15 } \\
\text { cycle }\end{array}$ & $\begin{array}{l}\text { domestic } \\
\text { cycle }\end{array}$ & $\begin{array}{l}\text { EU25 } \\
\text { cycle }\end{array}$ & $\begin{array}{l}\text { domestic } \\
\text { cycle }\end{array}$ & $\begin{array}{l}\text { EU25 } \\
\text { cycle }\end{array}$ \\
\hline & -0.43 & -0.39 & -0.39 & -0.39 & 0.26 & 0.28 & 0.12 & 0.18 \\
\hline$\left.{ }^{\mathrm{Du}}\right|_{t-1}$ & $(3.02) * * *$ & $(3.12)^{* * * *}$ & $(4.01)^{* * *}$ & $(3.97) * * *$ & $(9.66)^{* * *}$ & $(6.88)^{* * * *}$ & $(3.02)^{* * *}$ & $(4.63)^{* * *}$ \\
\hline \multirow[t]{2}{*}{ roe } & -0.09 & -0.10 & -0.09 & -0.08 & -0.03 & -0.03 & -0.03 & -0.03 \\
\hline & $(1.66) * *$ & $(0.98)$ & $(0.23)$ & $(3 . .2)^{* * *}$ & $(1.27)^{*}$ & $(4.01)^{* * *}$ & $(0.45)$ & $(0.66)$ \\
\hline \multirow{2}{*}{ risk } & -31.69 & -68.75 & -30.06 & -28.74 & 22.66 & 26.78 & 86.35 & 77.84 \\
\hline & $(4.02)^{* * *}$ & $(4.66)^{* * *}$ & $(2.99)^{* * * *}$ & $(3.15)^{* * *}$ & $(1.45)^{*}$ & $(1.75) * *$ & $(3.05)^{* * * *}$ & $(4.66)^{* * * *}$ \\
\hline \multirow[t]{2}{*}{ size } & -3.24 & -2.97 & 5.66 & 6.32 & -10.54 & -12.55 & 10.69 & 11.87 \\
\hline & $(4.52)^{* * *}$ & $(4.21)^{* * *}$ & $\begin{array}{c}(4.06)^{* * * *} \\
66.32\end{array}$ & $\begin{array}{c}(4.21)^{* * *} \\
78.56\end{array}$ & $(4.66)^{* * *}$ & $(5.74)^{* * *}$ & $\begin{array}{l}(1.65)^{*} \\
82.47\end{array}$ & $\begin{array}{l}(2.46)^{* *} \\
90.57\end{array}$ \\
\hline \multirow{5}{*}{$\begin{array}{l}\text { cycle } \\
\text { sloan } \\
\text { net loans }\end{array}$} & & & $(4.02)^{* * *}$ & $(4.51)^{* * *}$ & & & $(4.66)^{* * * *}$ & $(4.06)^{* * * *}$ \\
\hline & $\begin{array}{l}-0.46 \\
(4.55)^{* * *}\end{array}$ & $\begin{array}{l}-0.40 \\
(6.33) * * *\end{array}$ & $\begin{array}{l}-0.06 \\
(4.55)^{* * * *}\end{array}$ & $\begin{array}{l}-0.38 \\
(5.78) * * *\end{array}$ & $\begin{array}{c}0.10 \\
(2.02)^{* *}\end{array}$ & $\begin{array}{l}0.25 \\
(3.97)^{* * *}\end{array}$ & $\begin{array}{l}0.19 \\
(255)^{* *}\end{array}$ & 0.16 \\
\hline & & & -0.02 & -0.01 & & & -0.06 & -0.08 \\
\hline & & & $(3.13)^{* * *}$ & $(4.12)^{* * *}$ & & & $(3.11)^{* * *}$ & $(3.25)^{* * * *}$ \\
\hline & & & $\begin{array}{c}0.01 \\
(2.99)^{* * *}\end{array}$ & $\begin{array}{l}0.00 \\
(2.87)^{* * *}\end{array}$ & & & $\begin{array}{r}-0.01 \\
(0.11)\end{array}$ & $\begin{array}{c}-0.02 \\
(0.55)\end{array}$ \\
\hline \multirow{2}{*}{ sargan } & & & & & & & & \\
\hline & $32.58(0.99)$ & $29.87(0.55)$ & $26.89(0.63)$ & $27.96(0.79)$ & $25.67(0.85)$ & $21.46(0.92)$ & $22.97(0.46)$ & $23.69(0.76)$ \\
\hline \multirow{2}{*}{$\begin{array}{l}a(1) \\
a(2)\end{array}$} & $-1.44(0.00)$ & $-1.68(0.00)$ & $-0.96(0.00)$ & $-1.02(0.00)$ & $-1.76(0.00)$ & $-1.67(0.00)$ & $-1.55(0.00)$ & $-1.67(0.00)$ \\
\hline & $-1.62(0.26)$ & $-1.79(0.71)$ & $-1.24(0.82)$ & $-1.34(0.23)$ & $-1.21(0.75)$ & $-0.99(0.55)$ & $-0.92(0.65)$ & $0.76(0.98)$ \\
\hline
\end{tabular}

Note: Dependent variable is $B U F_{i t}$. Other variables as defined in Table 3 .

$T$-values presented in parentheses. $a(1)$ and $a(2)$ represent first and second order residual tests.

*, **, *** denote significance at the ten, five and one percent levels of significance respectively.

Cycle variable corresponds to real GDP growth. Models including the broad and the sub-group cycle are estimated separately. 
Table 6: EU15 Two-Step GMM Estimates by Type and Size of Bank

\begin{tabular}{|c|c|c|c|c|c|c|c|c|c|c|}
\hline \multirow[b]{2}{*}{ Cycle variable: } & \multicolumn{2}{|c|}{ Commercial banks } & \multicolumn{2}{|c|}{ Co-operative banks } & \multicolumn{2}{|c|}{ Savings banks } & \multicolumn{2}{|c|}{ Big banks } & \multicolumn{2}{|c|}{ Small banks } \\
\hline & $\begin{array}{l}\text { domestic } \\
\text { cycle }\end{array}$ & EU15 cycle & $\begin{array}{l}\text { domestic } \\
\text { cycle }\end{array}$ & EU15 cycle & $\begin{array}{l}\text { domestic } \\
\text { cycle }\end{array}$ & EU15 cycle & $\begin{array}{l}\text { domestic } \\
\text { cycle }\end{array}$ & EU15 cycle & $\begin{array}{l}\text { domestic } \\
\text { cycle }\end{array}$ & EU15 cycle \\
\hline & 0.33 & 0.21 & -0.15 & 0.19 & -0.17 & -0.16 & 0.44 & 0.30 & 0.25 & 0.15 \\
\hline but $_{t-1}$ & $(4.00) * * *$ & $(4.11)^{* * *}$ & $(0.60)$ & $(0.77)$ & $(1.46)^{*}$ & $(3.04)^{* * * *}$ & $(6.00) * * *$ & $(4.66)^{* * * *}$ & $(3.33)^{* * * *}$ & $(3.21)^{* * *}$ \\
\hline roe & -0.03 & -0.04 & -0.01 & -0.02 & -0.04 & -0.06 & -0.10 & -0.7 & -0.04 & -0.03 \\
\hline & $(1.52)^{*}$ & $(1.33)^{*}$ & $(0.70)$ & $(1.32)^{*}$ & $(4.01)^{* * *}$ & $(4.66)^{* * * *}$ & $(3.99)^{* * * *}$ & $(3.12)^{* * *}$ & $(1.86)^{* *}$ & $(1.97)^{*}$ \\
\hline risk & 26.55 & 22.46 & 40.55 & 70.44 & -31.22 & -22.54 & 40.25 & 69.68 & 29.66 & 55.78 \\
\hline & $(2.11)^{* *}$ & $(2.12)^{* *}$ & $(3.62)^{* * *}$ & $(3.17)^{* * *}$ & $(4.11)^{* * *}$ & $(3.66)^{* * * *}$ & $(2.25)^{* *}$ & $(2.52)^{* * *}$ & $(2.23)^{* *}$ & $(2.09)^{* *}$ \\
\hline size & $\begin{array}{l}0.56 \\
(0.77)\end{array}$ & $\begin{array}{l}0.33 \\
(0.17)\end{array}$ & $\begin{array}{l}-0.96 \\
(11.66)^{* * *}\end{array}$ & $\begin{array}{l}-7.22 \\
(4.62)^{* * * *}\end{array}$ & $\begin{array}{l}-0.76 \\
(0.97)\end{array}$ & $\begin{array}{l}0.35 \\
(0.77)\end{array}$ & $\begin{array}{l}-0.10 \\
(5.44)^{* * *}\end{array}$ & $\begin{array}{c}-6.59 \\
(4.22) * * *\end{array}$ & $\begin{array}{c}3.62 \\
(3.68)^{* * * *}\end{array}$ & $\frac{1.12}{(2.11)^{* *}}$ \\
\hline profit & 146.89 & 137.66 & 130.22 & 120.66 & 170.22 & 140.66 & 201.46 & 160.35 & 130.22 & 88.66 \\
\hline & $(4.00)^{* * * *}$ & $(4.11)^{* * *}$ & $(3.00)^{* * *}$ & $(1.85)^{* *}$ & $(4.06)^{* * *}$ & $(4.98) * * *$ & $(3.88)^{* * * *}$ & $(2.93)^{* * * *}$ & $(2.99)^{* * * *}$ & $(4.01)^{* * *}$ \\
\hline cycle & $\begin{array}{l}-0.16 \\
(125)^{*}\end{array}$ & $\begin{array}{l}-0.45 \\
(2.77)^{* *}\end{array}$ & $\begin{array}{l}0.15 \\
(2.18)^{* *}\end{array}$ & 0.22 & -0.10 & -0.37 & -0.12 & -0.55 & 0.06 & 0.20 \\
\hline Aloan & $\begin{array}{l}(1.25)^{*} \\
-0.03\end{array}$ & $\begin{array}{l}(2.77)^{* 6} \\
-0.02\end{array}$ & $\begin{array}{c}(2.18)^{* 27} \\
0.00\end{array}$ & $\begin{array}{l}(0.84) \\
0.03\end{array}$ & $\begin{array}{c}(3.00)^{* 2 * x} \\
0.01\end{array}$ & $\begin{array}{l}(4.61)^{*+2 x} \\
-0.01\end{array}$ & $\begin{array}{l}(2.53)^{* 4} \\
-0.01\end{array}$ & $\begin{array}{l}(1.63)^{*} \\
-0.02\end{array}$ & $\begin{array}{c}(2.99)^{* 27} \\
0.00\end{array}$ & $\begin{array}{l}(2.97)^{7+2 x+7} \\
-0.00\end{array}$ \\
\hline & $(4.62)^{* * *}$ & $(3.85)^{* * *}$ & $(3.66)^{* * *}$ & $(4.96)^{* * *}$ & $(0.75)$ & $(0.66)$ & $(6.33)^{* * *}$ & $(7.44)^{* * *}$ & $(0.12)$ & $(0.32)$ \\
\hline net loans & 0.10 & 0.00 & -0.25 & -0.03 & -0.09 & -0.01 & 0.01 & 0.01 & -0.12 & -0.01 \\
\hline & & $(0.12)$ & $(8.53)^{* * *}$ & $(4.00) * * *$ & $(1.88)^{*}$ & $(0.22)$ & $(3.01)^{*}$ & $(3.00)^{* * * *}$ & $(1.97)^{* * *}$ & $(1.86)^{*}$ \\
\hline Sargan & $42.44(0.78)$ & $34.66(0.63)$ & $27.89(0.93)$ & $25.67(0.86)$ & $22.97(0.79)$ & $33.79(0.67)$ & $31.75(0.92)$ & $22.97(0.78)$ & $23.67(0.81)$ & $22.75(0.84)$ \\
\hline$a(1)$ & $-1.66(0.00)$ & $-2.11(0.00)$ & $-1.75(0.00)$ & $-1.65(0.00)$ & $-1.88(0.00)$ & $1.35(0.00)$ & $-2.44(0.00)$ & $-3.13(0.00)$ & $-1.78(0.00)$ & $-1.44(0.00)$ \\
\hline$a(2)$ & $-1.21(0.74)$ & $-1.34(0.90)$ & $-1.66(0.96)$ & $-1.53(0.76)$ & $-1.57(0.83)$ & $-1.45(0.98)$ & $-1.76(0.80)$ & $1.45(0.76)$ & $-1.55(0.86)$ & $-1.63(0.76)$ \\
\hline
\end{tabular}

Note: Dependent variable is $B U F_{i t}$. Other variables as defined in Table 3.

$T$-values presented in parentheses. $a(1)$ and $a(2)$ represent first and second order residual tests.

$*, * *, * * *$ denote significance at the ten, five and one percent levels of significance respectively.

Cycle variable corresponds to real GDP growth. Models including the broad and the sub-group cycle are estimated separately. 


\section{Appendix 1: Country-Specific Regulatory Measures}

\section{EU15}

All of the countries in the EU15 sample have chosen to implement the BIS minimum of eight per cent as the requirement for internationally active banks. However, in addition to this, as discussed below, several countries have supplemented these rules with alternative measures to ensure soundness and stability.

\section{Spain}

In Spain, due to the concern of the Banco de Espaňa regarding the ability of Spanish banks to keep up with potential credit losses latent in the expansion of lending activity, capital requirement regulations were supplemented in June 2000 by a 'dynamic provisioning' system. The idea of the provisioning was based on the notion that funds are set against loans outstanding in each accounting time period, in line with and estimate of expected long-run losses. Essentially, the idea is to build up a provision during good times which is subsequently drawn from during bad times. The provision will increase when actual losses for one year are lower than expected, and is used against specific provisions in years when losses are higher than expected. The provisioning system therefore acts to smooth out cyclicality impacts of specific provisions on the profit and loss account.

The statistical provision is calculated using a bank's own internal method ${ }^{13}$, or alternatively, via a standard method recommended by the Banco de Espaňa. The standard method classifies exposures into six different categories, depending on their degree of riskiness, and each category is allocated a weight coefficient. ${ }^{14}$ The total provision is then equal to the sum of the requirements for all six categories. It is therefore unsurprising, as seen in Table 1, that the capital buffers of Spanish banks have remain relatively unchanged (around 3.6 per cent) since the implementation of the dynamic provisioning in June 2000.

\section{United Kingdom}

In addition to the basic requirements set out by the Basel Accord, the UK Financial Services Authority (FSA) various additional requirements are implemented to assure the safety and soundness of the banking sector. First, sets two separate requirements for each

\footnotetext{
${ }^{13}$ The regulator must verify that the model adopted characterizes a suitable means to measure and manage credit risk

${ }^{14}$ The coefficients range from 0 for zero risk exposures to 1.5 for high risk exposures.
} 
bank: a 'trigger ratio' and a 'higher target ratio'. The 'trigger ratio' serves as a minimum ratio which will generate regulatory intervention if infringed. The 'target ratio' serves as a warning signal and as a cushion of capital acting to prevent the accidental breach of the 'trigger ratio'. The gap between the 'target' and the 'trigger' ratio acts as a buffer in that regulatory pressure is exerted when the capital ratio falls below the 'target' but drastic regulatory action is only enforced in the event of a violation of the 'trigger ratio'. These ratios are bank specific and are based on the supervisor's perception of the degree of riskiness of the banking institution. Banks deemed by the supervisor to be more (less) risky is required to hold higher (lower) levels of capital. Consequently, most UK banks are required to hold capital in excess of those specified by the EU directive. For the purpose of our estimations, we calculate the capital buffer for UK banks based on an assumed nine per cent minimum, since we are unable to obtain individual bank-specific requirement data.

\section{RAMS}

Banking policy for developing or transition economies generally tends to differ from that adopted for more developed markets. Since a stable financial system is vital for economic growth, the key questions for policy-makers in this context relate to the specific methods of bank regulation and supervision that can strengthen financial system regulation and supervision in order to promote more efficient and robust financial systems. Considering the largely varying degrees of development as well as the distinct differences that exist between the ram economies in terms of banking sector structures, it is unsurprising that the minimum capital adequacy ratio required of financial market operatives has varied across countries throughout our sample period.

Table 1 highlights the minimum ratios adopted in each of the ram countries. In Estonia and Cyprus, regulatory capital ratios have recently been tightened from eight to ten per cent of risk weighted assets to account for changes in market structure. In 1997, the Estonian authorities cited rapid growth of banks assets and changes in their operational environment as the main reasons for its higher regulatory ratio. In 2001, Cyprus raised its capital adequacy ratio to account for the increase in securities market activity. Latvia and Lithuania on the other hand both recently reduced their required ratios from ten to eight per cent effective from January $2005^{15}$.

In Poland, while banks are required to hold no more than the eight per cent regulatory minimum, 15 percent is the requisite ratio for banks in their first year of operation, and 12.5 percent in the second year.

\footnotetext{
${ }^{15}$ The ten percent regulatory minimum continues to be effective for AB VB Mortgage Bank in Lithuania.
} 


\section{Appendix 2: Checking for downward bias in the standard errors on aggregate variables}

We are concerned with a further econometric problem affecting all studies, such as our own, that combine macro-level and micro-data, whether in panel or cross-section. This problem, originally highlighted by Moulton (1990), is the downward bias on standard errors for macro-economic variables, when there is clustering of unobserved random variables. This possibility cannot be ignored since any omission of macro-economic variables, affecting the dependent variable, will lead to such clustering.

Correcting for clustering of unobserved variables can have a dramatic impact on reported significance levels. In the cross-sectional example reported by Moulton, standard errors on aggregate variables are biased upwards by a factor of around three. A change of this size would imply a fall for example in t-statistics from an apparently highly significant level of over 4, to a statistically insignificant level of less than 1.5.

Several methods have been proposed to deal with this problem, the most common being 'robust-cluster' adjustment of standard errors available in STATA. Unfortunately we have been unable to carry out this adjustment, since the adjustment is only available for the estimation of a static panel regression with random effects. The option to adjust our preferred dynamic fixed-effects regression models is not available. We instead conduct two alternative calculations in order to assess the magnitude of the resulting bias in the standard errors on our aggregate cyclical variables. ${ }^{16}$ First, we estimate a static random-effects version of our model, allowing us to then apply the 'robust-cluster adjustment' to the standard errors. For purposes of comparison we compare these estimates with those from a static fixed-effects version of our model as well as our preferred dynamic fixed effects model. We find that for each variable, without the 'robust cluster adjustment', the standard error in the static regression using either fixed or random effects are very similar. We find that using the 'robust-cluster adjustment', the standard error changes increases by on average by around 20 percent for each variable within each sub-sample. This suggests that, while clustering of errors reduces but does not totally overturn the significance of our results. We therefore conclude that our sample is affected to only a small extent by the problem of residual clustering identified by Moulton (1990).

\footnotetext{
${ }^{16}$ Details of these alternative calculations are reported in the working paper version of this article, JokiipI and Milne (2005).
} 